\title{
Morphological changes of carotid bodies in acute respiratory distress syndrome: a morphometric study in humans
}

E.N.G. Vinhaes,

M. Dolhnikoff and

P.H.N. Saldiva
Departamento de Patologia, Faculdade de Medicina,

Universidade de São Paulo, São Paulo, SP, Brasil

\section{Correspondence \\ M. Dolhnikoff, \\ Departamento de Patologia \\ Faculdade de Medicina, USP \\ Av. Dr. Arnaldo, 455 \\ 01246-903 São Paulo, SP \\ Brasil \\ Fax: + 55-11-3062-8098 \\ E-mail: maridol@usp.br}

Research supported by LIM 05 HC-FMUSP, CNPq and FAPESP.

Received May 25, 2001

Accepted May 22, 2002

\section{Abstract}

Carotid bodies are chemoreceptors sensitive to a fall of partial oxygen pressure in blood (hypoxia). The morphological alterations of these organs in patients with chronic obstructive pulmonary disease (COPD) and in people living at high altitude are well known. However, it is not known whether the histological profile of human carotid bodies is changed in acute clinical conditions such as acute respiratory distress syndrome (ARDS). The objective of the present study was to perform a quantitative analysis of the histology of carotid bodies collected from patients who died of ARDS. A morphometric study of carotid bodies collected during routine autopsies was carried out on three groups: patients that died of non-respiratory diseases (controls, $\mathrm{N}=8$ ), patients that presented COPD and died of its complications or associated diseases $(\mathrm{N}=7)$, and patients that died of $\operatorname{ARDS}(\mathrm{N}=7)$. Morphometric measurements of the volume fraction of clusters of chief cells were performed in five fields on each slide at 40X magnification. The numerical proportion of the four main histological cell types (light, dark, progenitor and sustentacular cells) was determined analyzing 10 fields on each slide at 400X magnification. The proportion of dark cells was 0.22 in ARDS patients, 0.12 in controls $(\mathrm{P}<0.001)$, and 0.08 in the COPD group. The proportion of light cells was 0.33 (ARDS), 0.44 (controls) $(\mathrm{P}<0.001)$, and 0.36 (COPD). These findings suggest that chronic and acute hypoxia have different effects on the histology of glomic tissue.

\section{Introduction}

Carotid bodies are nodular structures found in the angle of the bifurcation of the common carotid arteries. They are considered to be chemoreceptors sensitive to changes in the partial blood oxygen pressure. De Castro (1) showed that the innervation of the carotid body, originating from the glos-

\author{
Key words \\ - Carotid body \\ - Hypoxia \\ - Acute respiratory distress \\ syndrome \\ - Morphometry
}

sopharyngeal nerve, was afferent in nature and probably with sensory function. His interpretation about the histological features of the carotid body is considered to be the basis of the concept that this structure participates in blood gas monitoring (2-4). Heymans et al. (5) later demonstrated that the carotid body responds to the fall in partial oxygen pressure, the increase in partial $\mathrm{PCO}_{2}$ pres- 

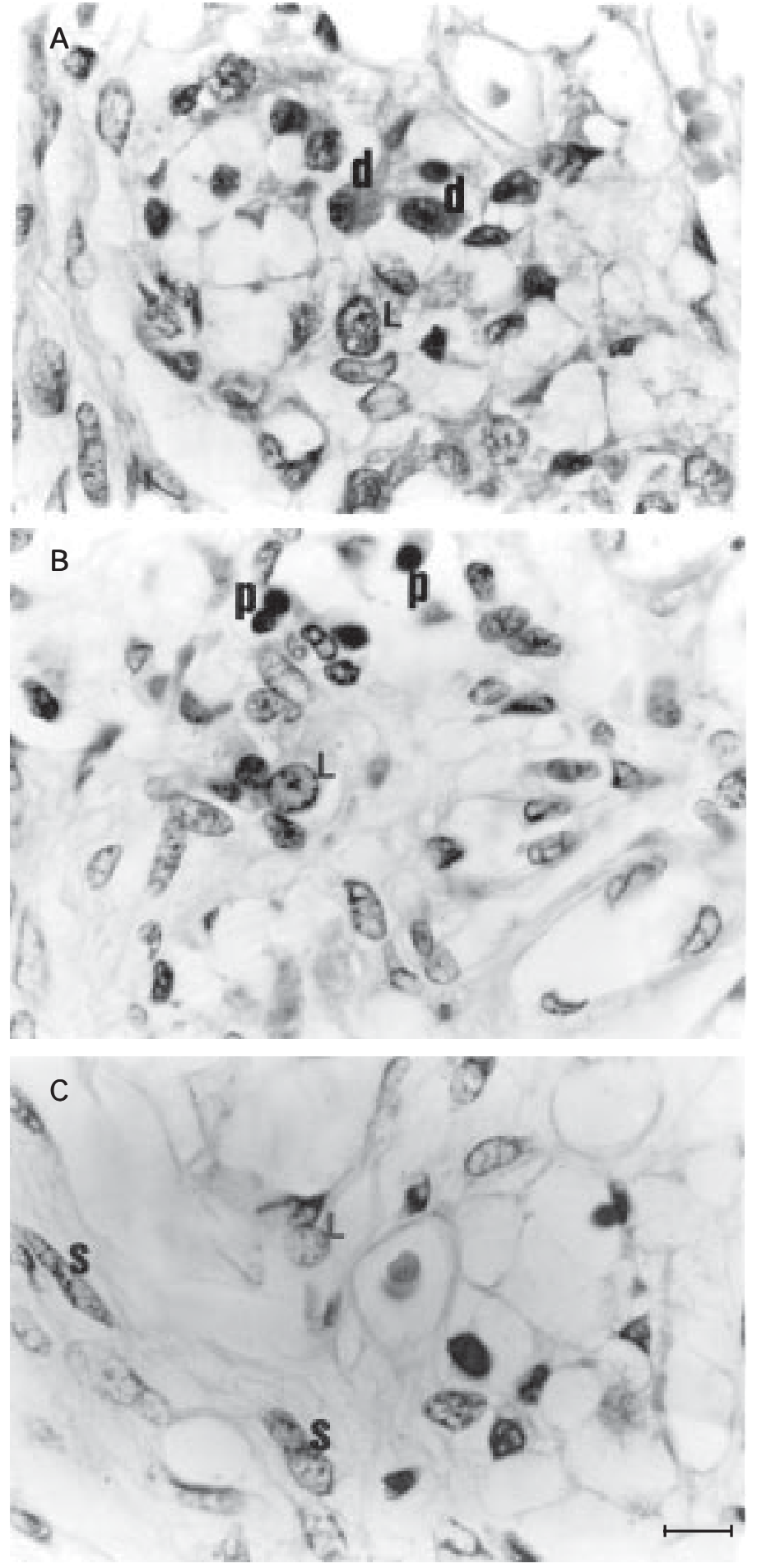

Figure 1. Photomicrographs of glomic cells. A, Light (L) and dark (d) cells in a cluster of chief cells, in a patient that died of acute myocardial infarction. B, Light (L) and progenitor ( $p$ ) cells in a patient that died of ARDS and systemic lupus erythematosus. C, Light (L) and sustentacular (s) cells in a patient that died of COPD and rupture of aortic aneurysm (HE; bar $=10 \mu \mathrm{m}$ ). sure and the fall in arterial blood $\mathrm{pH}$, contributing to the genesis of the hyperventilation observed under these conditions. Other factors such as temperature, osmolarity and arterial pressure, at least in animals, can stimulate the carotid body (6). Morphologically, the carotid body shows two different types of cells. First, forming clusters, there are the chief cells, with three subtypes (light, dark and progenitor) observed by staining with hematoxylin and eosin (Figure 1A,B). These cells are considered to be the chemoreceptor cells of the organ. At the level of electron microscopy, the chief cells contain electron-dense granules in their cytoplasm. Many substances have been demonstrated in these granules, mainly biogenic amines (dopamine, noradrenaline) and some peptides, but the physiological significance of these findings remains unknown. The second type, surrounding the clusters of chief cells, is represented by the sustentacular cells that envelope the nonmyelinated nervous filaments and enclose them to the surface of the chief cells (Figure 1C).

There is considerable evidence that carotid bodies can have their structure modified under several conditions, such as normocapnic hypoxia (7-9), chronic obstructive pulmonary disease (COPD) (10-12), aging (13), and arterial hypertension $(11,14)$. In these situations, the changes in the histology of carotid bodies have been presumed to provide a plausible structural basis for the functional abnormalities of respiratory control. For instance, chronic high altitude hypoxia has been associated with light cell hyperplasia (15-17); an increase of sustentacular cells has been clearly demonstrated in COPD (18-20). Thus, it is reasonable to assume that the cellular profile of carotid bodies can provide useful information about the physiopathology of the respiratory control. However, the relationship between the morphological and functional alterations of the structure in these situations remains obscure. 
If chronic hypoxia modifies the histological profile of the carotid bodies, one can speculate that acute episodes of hypoxia may promote histopathological changes as well. It has been well established that patients that survive acute respiratory distress syndrome (ARDS) may have abnormalities of respiratory control as demonstrated during weaning from mechanical ventilation (21). However, it is not known whether the histology of carotid bodies is modified in this situation.

The present study was designed to perform a quantitative analysis of the histology of carotid bodies collected at autopsy from patients that died of ARDS. The data were compared with those obtained for two different groups: patients with non-respiratory and non-chronic cardiovascular diseases (controls), and patients with COPD. Patients with COPD were included in the study because the changes found in the glomic tissue in this clinical situation have been well documented $(11,12,19)$.

\section{Patients and Methods}

Carotid bodies were collected during routine autopsies performed at our Medical School. Clinical information was obtained from hospital charts and the diagnosis was confirmed at autopsy. Patients were divided into three groups: deaths caused by nonrespiratory diseases (group $\mathrm{I}, \mathrm{N}=8$ ), patients with COPD who died of its complications or associated diseases (group II, $\mathrm{N}=7$ ), and patients who died of ARDS (group III, $\mathrm{N}=$ 7). For group III, no restrictions were made about time of mechanical ventilation and inspired fraction of oxygen. In all of these patients the duration of ARDS was less than one week. Clinical information about these patients is presented in Table 1.

At autopsy, patients from group I showed no significant changes in lung histology or signs of chronic cardiovascular diseases. Patients with ARDS showed marked histological changes in lung parenchyma, includ- ing alveolar infiltration of inflammatory cells, intra-alveolar exudate with hyaline membranes, alveolar hemorrhage and septal thickening by loose connective tissue.

In order to collect the carotid bodies, the common carotid artery on each side of the neck was dissected up to above its bifurcation and the whole piece ( $3 \mathrm{~cm}$ above and 5 $\mathrm{cm}$ below the bifurcation) was placed in buffered formalin for $48 \mathrm{~h}$. After this, the carotid body was gently dissected with the aid of a 25X magnifying glass (Carl Zeiss, Germany) and routinely processed for paraffin embedding and histological sectioning. Five-micrometer thick sections were stained with hematoxylin and eosin. The two carotid bodies (left and right) of each patient were studied. One section per carotid body was analyzed.

Morphometric measurements were performed by standard point-counting procedures with an integrating eyepiece (Instru-

Table 1. Age, sex and main diagnosis of the patients studied.

\begin{tabular}{rccll}
\hline Case & Group & Age (years) & Sex & Main diagnosis \\
\hline 1 & I & 70 & M & Acute myocardial infarction \\
2 & I & 41 & M & Acute myocardial infarction \\
3 & I & 59 & M & Gastric tumor \\
4 & I & 67 & M & Gastric tumor \\
5 & I & 60 & F & Acute myocardial infarction \\
6 & I & 75 & M & Pancreatic tumor \\
7 & I & 50 & M & Acute myocardial infarction \\
8 & I & 33 & M & AIDS + cryptococcosis \\
9 & II & 75 & M & COPD + cor pulmonale \\
10 & II & 82 & M & COPD + cerebral infarction \\
11 & II & 59 & M & COPD + cor pulmonale \\
12 & II & 81 & M & COPD + bronchopneumonia \\
13 & II & 59 & M & COPD + bronchopneumonia \\
14 & II & 58 & M & COPD + rupture of aortic aneurysm \\
15 & II & 74 & M & COPD + acute myocardial infarction \\
16 & III & 17 & M & ARDS + septicemia \\
17 & III & 23 & M & ARDS + systemic lupus erythematosus \\
18 & III & 22 & M & ARDS + leptospirosis \\
19 & III & 54 & M & ARDS + septic shock \\
20 & III & 74 & M & ARDS + septic shock \\
21 & III & 40 & M & ARDS + leptospirosis \\
22 & III & 18 & F & ARDS + cerebral hemorrhage \\
& & & &
\end{tabular}

Data were obtained from patient charts. The main diagnosis was confirmed at autopsy. Groups: I = control, II = chronic obstructive pulmonary disease (COPD), III = acute respiratory distress syndrome (ARDS). $M=$ male, $F=$ female. 

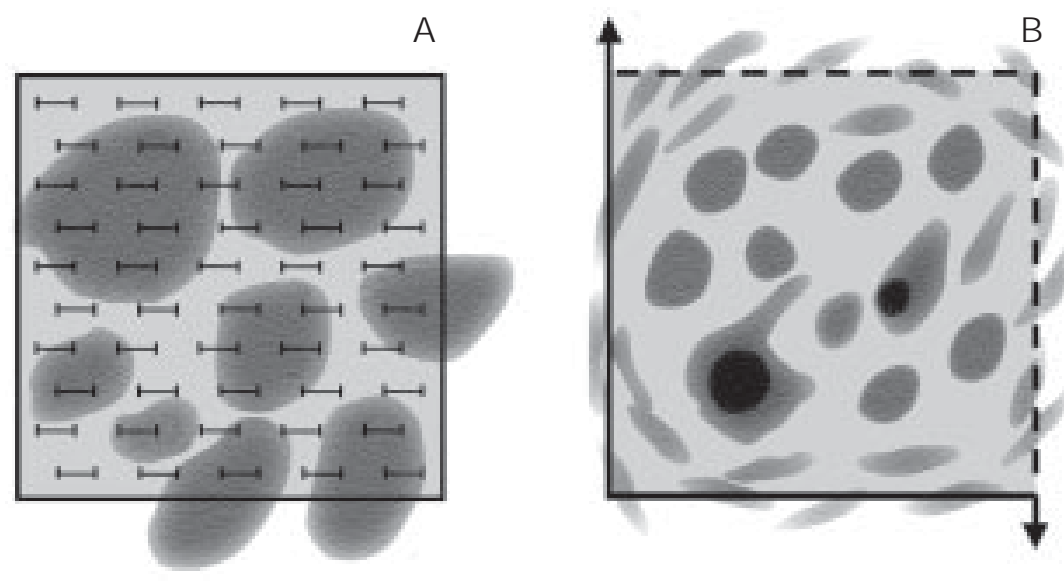

Figure 2. Morphometric studies of glomic tissue. A, Schematic representation of the morphometric measurement of the volume fraction of clusters of chief cells (Vc) using the standard point-counting procedure (40X). Vc was obtained using the $\mathrm{Vc}=\mathrm{pC} /$ ptot ratio, where $\mathrm{pC}$ represents the number of points hitting chief cell clusters and ptot is the total number of points considered for each microscopic field. B, Schematic representation of clusters of chief cells in one microscopic field (1000X). The upper and right limits of the integrating eyepiece (dashed lines) were considered the exclusion limits. The proportion $\mathrm{P}$ of the main histological cell types ( $\mathrm{P}_{\text {light }}, \mathrm{P}_{\text {dark }}, \mathrm{P}_{\text {progenitor }}$ and $\mathrm{P}_{\text {sustent }}$ ) was obtained by dividing the numerical density of each cell profile by the total number of profiles counted.

Table 2. Morphometric parameters of carotid bodies in control, COPD and ARDS groups.

\begin{tabular}{llllll}
\hline Group & & Mean & Maximum & Minimum & $\begin{array}{c}\text { Standard } \\
\text { deviation }\end{array}$ \\
\hline Control $(\mathrm{N}=9)$ & Plight & 0.4372 & 0.5242 & 0.3477 & 0.0610 \\
& Pdark & 0.1245 & 0.2683 & 0.0703 & 0.0620 \\
& Pprogenitor & 0.0491 & 0.0796 & 0.0164 & 0.0221 \\
& Psustent & 0.3892 & 0.4441 & 0.3126 & 0.0454 \\
& Vc & 0.6273 & 0.8750 & 0.3650 & 0.1942 \\
COPD $(\mathrm{N}=7)$ & Plight & 0.3638 & 0.4237 & 0.3238 & 0.0299 \\
& P & 0.0814 & 0.1556 & 0.0456 & 0.0249 \\
& Pprogenitor & 0.0416 & 0.1086 & 0.0201 & 0.0311 \\
& Psustent & 0.5133 & 0.5714 & 0.3728 & 0.0519 \\
& Vc & 0.3553 & 0.7875 & 0.1680 & 0.2166 \\
ARDS $(\mathrm{N}=7)$ & Plight & 0.3277 & 0.3744 & 0.2788 & 0.0332 \\
& Pdark & 0.2204 & 0.2927 & 0.1624 & 0.0545 \\
& Pprogenitor & 0.0663 & 0.1294 & 0.0310 & 0.0329 \\
& Psustent & 0.3857 & 0.4985 & 0.2658 & 0.0881 \\
& Vc & 0.6527 & 0.8200 & 0.3630 & 0.1556 \\
\hline
\end{tabular}

Data are reported as means for each group. COPD = chronic obstructive pulmonary disease; $A R D S=$ acute respiratory distress syndrome; $P_{\text {light }}=$ proportion of light cells; $\mathrm{P}_{\text {dark }}=$ proportion of dark cells; $\mathrm{P}_{\text {progenitor }}=$ proportion of progenitor cells; $\mathrm{P}_{\text {sustent }}=$ proportion of sustentacular cells; $\mathrm{Vc}=$ volume fraction of clusters of chief cells. The patients are described in Table 1. mentação Técnica Científica, São Paulo, SP, Brazil) containing 50 lines and 100 points. We determined the volume fraction of clusters of chief cells $(\mathrm{Vc})$ at $40 \mathrm{X}$ magnification. Briefly, five non-coincident fields on each slide were examined across a surface cut of the carotid body. For each field, 100 points were counted and $\mathrm{Vc}$ was determined by the following relationship: $\mathrm{Vc}=\mathrm{pC} / \mathrm{ptot}(1)$, where $\mathrm{pC}$ represents the number of points hitting chief cell clusters and ptot is the total number of points considered for each microscopic field (Figure 2A).

In addition to $\mathrm{Vc}$, the number of profiles of the four main histological subtypes of glomic tissue - light, dark, progenitor and sustentacular cells (4) - was determined in 10 non-coincident microscopic fields on each slide at 400X magnification using the unbiased procedure described by Gundersen et al. (22), whereby the cell profiles are counted in each field respecting the inclusion and exclusion limits of the integrating eyepiece (Figure 2B).

The proportion $\mathrm{P}$ of the main histological cell types - $\mathrm{P}_{\text {light }}, \mathrm{P}_{\text {dark }}, \mathrm{P}_{\text {progenitor }}$ and $\mathrm{P}_{\text {sustent }}$, respectively, within the glomus was computed by dividing the numerical density of each cell profile by the total number of profiles counted.

Groups were compared by analysis of variance (ANOVA), with the level of significance set at $5 \%$. When a significant difference was detected, multiple comparisons among the groups were performed by the Student-Newman-Keuls test. Logarithmic transformations were applied when necessary in order to test the sensitivity of the results to heteroscedasticity. The statistical calculations were done with the aid of the SPSS v6.0 software (23).

\section{Results}

The results of the morphometric measurements obtained for the different groups are shown in Table 2. Table 3 shows the 
ANOVA output. Patients with COPD had an increase in sustentacular cells and reduced glomic tissue when compared to controls. Patients with ARDS had a significantly higher number of dark cells and a reduction of light cells compared to COPD and controls. These findings suggest that chronic and acute hypoxia have different effects on the histology of glomic tissue.

\section{Discussion}

In this study our objective was to determine whether ARDS would change the cellular profile of the carotid body, since this is an acute clinical condition characterized by severe hypoxia with a high mortality rate despite an increase in the inspired fraction of oxygen (24-26). We had a "positive control", since we observed a significant increase in the number of sustentacular cells in COPD, as already shown by others $(18,19)$. Although the studies of carotid bodies in COPD patients previously performed did not use unbiased morphometric methods, proliferation of type II cells (sustentacular cells) in hypoxic patients has been reported (10-12). We also observed that the amount of glomic tissue in COPD was reduced in comparison to that of the connective tissue that limits the lobules within the carotid body, suggesting that the parenchyma of COPD patients shows reduced chemosensitivity.

ARDS patients had a different histological profile, with marked reduction of light cells and an increase in dark cells when compared to controls. It is interesting to note that the patients in the ARDS group were younger than in the other groups. The difference in age could be a factor that affects the histological profile of carotid bodies since there is a predominance of dark cells in the chief cell population of children and young adults. However, even the three oldest patients in the ARDS group had an increased dark cell population when compared to con- trols (mean values of $\mathrm{P}_{\text {dark }}=0.125$ ) and the COPD group. Table 4 shows individual values of $\mathrm{P}_{\text {dark }}$ in ARDS patients.

What could be the mechanisms responsible for the increase of dark cells in ARDS? Since the increase in dark cells occurred at the same time as a decrease in light cells, it is tempting to consider that these two cell types are variants of the same cell, as suggested by Verna (27). The increase in the dark cell population observed in ARDS could reflect a higher functional activity of carotid bodies in response to hypoxia. In an elegant study, Biscoe and Stehbens (28) investigated in detail the ultrastructural aspects of glomic cells, suggesting that dark cells have a highly complex secretory structure, presenting a large number of electron-dense granules, most probably containing biogenic amines. Furthermore, the number of electron-dense granules seemed to be increased in chief cells after exposure to acute hypoxia in rabbits (29). Jago et al. (30) suggested that the increase in electron-dense granules was more pronounced in dark cells in a patient with arterial hypertension, leading to a darker cytoplasm at the ultrastructural level. In the human carotid body, dopamine is the bio-

Table 3. ANOVA output of the multiple comparisons among the groups.

\begin{tabular}{lll}
\hline$P_{\text {dark }}$ & $\mathrm{P}<0.001$ & ARDS different from all others \\
$\mathrm{P}_{\text {light }}$ & $\mathrm{P}<0.001$ & Control different from ARDS and COPD \\
$\mathrm{P}_{\text {sustent }}$ & $\mathrm{P}=0.002$ & COPD different from all others \\
$\mathrm{P}_{\text {progenitor }}$ & $\mathrm{P}=0.282$ & No differences among groups \\
Vc & $\mathrm{P}=0.015$ & COPD different from all others
\end{tabular}

Data were obtained by comparison of the groups using analysis of variance (ANOVA), with the level of significance set at $5 \%$. When a significant difference was observed, multiple comparisons among the groups were performed by the Student-NewmanKeuls test. For abbreviations see legend to Table 2.

Table 4. Age and proportion of dark cells $\left(\mathrm{P}_{\text {dark }}\right)$ of patients with acute respiratory distress syndrome.

\begin{tabular}{lccccccc}
\hline Age (years) & 17 & 18 & 22 & 23 & 40 & 54 & 74 \\
$P_{\text {dark }}$ & 0.286 & 0.279 & 0.163 & 0.180 & 0.179 & 0.192 & 0.239 \\
Patient & 1 & 7 & 3 & 2 & 6 & 4 & 5
\end{tabular}

$P_{\text {dark }}$ is the mean value for each patient (10 microscopic fields for each patient). 
genic amine present at the highest concentration in the electron-dense granules (31), but, interestingly enough, dopamine is considered to decrease the respiratory response to hypoxia (32). The functional significance of these observations remains to be clarified.

Since dark cells can represent a higher functional status of chief cells, an increased number of dark cells in ARDS could be seen as an adaptive response to low arterial oxygen tension. Consistent with the foregoing view is the report that dark cell hyperplasia was observed in Dutch rabbits kept on Monte Bianco at an altitude of $3370 \mathrm{~m}$ for 3 months. However, the number of dark chief cells returned to normal values $(11 \%)$ when the rabbits were left at the same altitude for a period of 6 months (33). Furthermore, the carotid bodies from patients with asthma also present an increased number of dark chief cells (34) and this response is considered the first morphological alteration of the carotid body cells after exposure to hypoxia (4).
The morphological changes observed in carotid bodies in ARDS indicate that functional alterations of respiratory chemosensitivity may be present in these patients. In this scenario, our results indicate that studies focusing on respiratory control should be done in patients surviving ARDS in order to determine to what extent the difficulties of weaning from the ventilator are related to abnormal respiratory drive.

Our results demonstrate that patients with ARDS present an increase of the numerical fraction of dark cells in their carotid bodies. These findings are consistent with an initial response of these structures to acute hypoxia and indicate the necessity for functional studies of respiratory control in patients surviving ARDS.

\section{Acknowledgments}

The authors thank Dr. Thais Mauad for critical comments and suggestions.

\section{References}

1. de Castro F (1928). Sur la structure et l'innervation du sinus carotidien del' homme et des mammiféres. Nouveaux faits sur l'innervation et la fonction du glomus caroticum. Travaux du Laboratoire de Recherches Biologiques de I'Université de Madrid, 25: 331-380.

2. Grimley PM \& Glenner GG (1968). Ultrastructure of the human carotid body. A perspective on the mode of chemoreception. Circulation, 37: 648-665.

3. Grönblad M (1983). Function and structure of the carotid body. Medical Biology, 61: 229-248.

4. Smith P (1995). Carotid body and pulmonary glomera in cardiorespiratory disease. In: Spencer J (Editor), Spencer's Pathology of the Lung. 5th edn. McGraw-Hill Companies, Inc., Seattle, WA, USA.

5. Heymans C, Bouckhaert JJ \& Dautrebande L (1930). Sinus carotidien et réflexes respiratoires. II. Influences respiratoires réflexes de l'acidôse de l'alcalose, de l'anhydride carbonique, de l'ion hydrogéne et de l'anoxémie: Sinus carotidiens et échanges respiratoires dans le poumons et au delá des poumons. Archives Intemationales de Pharmacodynamie et de Therapie, 39: 400-448.

6. Eyzaguirre C \& Zapata P (1984). Perspectives in carotid body research. J oumal of Applied Physiology, 57: 931-957.

7. Lack EE (1977). Carotid body hypertrophy in patients with cystic fibrosis and cyanotic heart disease. Human Pathology, 8: 39-51.

8. Lack EE (1978). Hyperplasia of vagal and carotid body paraganglia in patients with chronic hypoxemia. American J ournal of Pathology, 19: 497-516.

9. Lack EE, Perez-Atayde AR \& Young JB (1985). Carotid body hyperplasia in cystic fibrosis and cyanotic heart disease. A combined morphometric, ultrastructure, and biochemical study. American J ournal of Pathology, 119: 301-314.

10. Heath D, Edwards C \& Harris P (1970). Post-mortem size and structure of the human carotid body. Its relation to pulmonary disease and cardiac hypertrophy.
Thorax, 25: 129-140.

11. Edwards C, Heath D \& Harris P (1971). The carotid body in emphysema and left ventricular hypertrophy. J ournal of Pathology, 104: 1-13.

12. Habeck J-O (1986). Morphological findings at the carotid bodies of humans suffering from different types of systemic hypertension or severe lung diseases. Anatomischer Anzeiger, 162: 17-27.

13. Hurst G, Heath D \& Smith P (1985). Histological changes associated with ageing of the human carotid body. J ournal of $\mathrm{Pa}$ thology, 147: 181-187.

14. Heath D, Smith P \& Hurst G (1986). The carotid body in coarctation of the aorta. British J ournal of Diseases of the Chest, 80: $122-130$.

15. Arias-Stella J (1969). Human carotid body at high altitudes. American J oumal of $\mathrm{Pa}$ thology, 55: 82 (Abstract).

16. Arias-Stella J \& Vacarel J (1973). The human carotid body at high altitudes. Pathologia et Microbiologia, 39: 292-297.

17. Khan Q, Heath $D \&$ Smith P (1988). Ana- 
tomical variations in human carotid bodies. J ournal of Clinical Pathology, 41: 1196-1199.

18. Heath D, Smith P \& J ago R (1982). Hyperplasia of the carotid body. J ournal of Pathology, 138: 115-127.

19. Smith P, J ago R \& Heath D (1982). Anatomical variations and quantitative histology of the normal and enlarged carotid body. J ournal of Pathology, 137: 287-304.

20. Heath D (1991). The human carotid body in health and disease. J ournal of Pathology, 164: 1-8.

21. Hansen-Flaschen J \& Fishman AP (1992). Síndrome da distração respiratória do adulto: Características clínicas e patogênese. In: Fishman AP (Editor), Diagnóstico das Doenças Pulmonares. Manole, São Paulo, SP, Brazil.

22. Gundersen HJ G, Bendtsen TF, Korbo L, Marcussen N, Moller A, Nielsen $K$, Nyengaard J R, Pakkenberg FB, Sorensen FB, Vesterby A \& West MJ (1988). Some new, simple and efficient stereological methods and their use in pathological research and diagnosis. Acta Pathologica,
Microbiologica et Immunologica Scandinavica, 96: 379-394.

23. SPSS version 6.0. (1990). SPSS Inc., Chicago, IL, USA.

24. Demiling RH (1995). The modem version of adult respiratory distress syndrome. Annual Review of Medicine, 46: 193-202.

25. Luce J M (1998). Acute lung injury and the acute respiratory distress syndrome. Critical Care Medicine, 26: 369-376.

26. Ranieri VM, Suter PM, Tortorella $C$, De Tullio R, Dayer J M, Brienza A, Bruno F \& Slutsky AS (1999). Effect of mechanical ventilation on inflammatory mediators in patients with acute respiratory distress syndrome. A randomized controlled trial. J ournal of the American Medical Association, 7: 54-61.

27. Verna A (1997). The mammalian carotid body: Morphological data. In: González C (Editor), The Carotid Body Chemoreceptors. Medical Intelligence Unit, New York, NY, USA.

28. Biscoe TJ \& Stehbens WE (1966). Ultrastructure of the carotid body. J ournal of Cell Biology, 30: 563-578.
29. Moller M, Mollagard K \& Sorensen SC (1974). The ultrastructure of the carotid body in chronically hypoxic rabbits. J ournal of Physiology, 238: 443-447.

30. J ago R, Smith $P \&$ Heath D (1985). Electron microscopy of carotid body hyperplasia. Archives of Pathology and Laboratory Medicine, 108: 717-722.

31. Steele RH \& Hinterberger H (1972). Catecholamines and 5-hydroxytryptamine in the carotid body in vascular, respiratory, and other diseases. J ournal of Laboratory and Clinical Medicine, 80: 63-70.

32. Barer G (1994). Carotid body in animal models of human disease: what do they teach us? Thorax, 49 (Suppl): 14-18.

33. Smith $P$, Heath $D$, Williams $D$, Bencini $C$, Pulera N \& Giuntini C (1993). The earliest histopathological response to hypobaric hypoxia in rabbits in the refugio Torino (3370 m) on Monte Bianco. J ournal of Pathology, 170: 485-491.

34. Bencini C \& Pulera N (1991). The carotid bodies in bronchial asthma. Histopathology, 18: 195-200. 